navvy nation-hewers of wood and drawers of water for more educated peoples. In certain respects Great Britain was approaching that position in 1914. The War gave us a temporary respite, but the never-ending economic industrial struggle is still with us, and in this contest the intimate blend of chemistry and engineering presented by the Institution of Chemical Engineers must take an increasingly important part.

\section{Elm Disease in Great Britain}

A Furthen survey to determine the course of elm disease in Great Britain was carried out recently by Mr. T. R. Peace, of the Imperial Forestry Institute, Oxford, on the instructions of the Forestry Commissioners. Three counties have now to be added to the list of those in which the disease is known to occur, namely Durham, Derbyshire and Dorset. The characteristic symptoms of elm disease, namely dieback of the crown, appeared this year rather earlier than usual and by the end of July so many cases were seen that a heavy attack appeared probable. Surprisingly few further cases, however, developed during August and September and the final result may be stated as showing a definite increase over 1932 but a decrease as compared with 1931. The general position in England is unchanged from that of previous years. The disease remains serious in parts of the eastern counties; but severe damage is of local occurrence. In the South Midlands and in the south eastern counties the disease is frequent but seldom serious. Towards the west and north it is sporadic and has not been found north of a line between Durham and Chester, in the western counties of Wales, or in Cornwall. Having regard to the recent dry summer, it may be considered satisfactory that the disease has not spread more rapidly or done a larger amount of damage than appears to be the case. An interesting observation made during the course of the survey relates to the north of England and Scotland. Many of the older trees, mostly wych elms, showed signs of die-back elosely resembling those caused by the elm disease, but distinguished from the latter by the absence of the characteristic markings in the twigs and by one or two more general characters such as the browning of the leaves round the edges. The cause of the trouble, which is widespread, is under investigation.

\section{The Communication Revolution, 1760-1933}

AFTER the delivery of the presidential address by Mr. H. W. Dickinson to the Newcomen Society on October 11, a paper with the above title was read, by Prof. R. G. Albion of Princeton University. Taking the opening of Brindley's Bridgewater Canal as his starting point, Prof. Albion touched upon the development of canals, roads, railways, steam. ships, telegraphs and submarine cables, electric traction, motor-ears, telephones, aeroplanes and radio, and briefly referred to the effect of the 'communication revolution' on commerce, finance, exploration, colonisation, government, warfare, city growth and also to its influence on the individual. His paper contained many interesting comparisons of the facilities for communication in the eighteenth century and to-day. Just as stage coaches in England sometimes took 14 days to go from London to Edinburgh, so travellers were often a week going from Boston to New York, while one landmark in colonial travel was the inauguration in 1770 of a two-day service between New York and Philadelphia, a distance of but 90 miles. The first shots in the American Revolution were fired at Lexington on April 19, 1775, and the news did not reach New York, 225 miles distant, until four days later. The United States, Prof. Albion said, would probably have never fought England in 1812 had there been an Atlantic cable, for England suspended the Orders in Council, the chief American grievance, the day before War was declared at Washington. Rapidity of communication has also revolutionised business transactions, and although the Rothschilds once maintained an elaborate service of correspondents and couriers for business purposes, their information was neither so full nor so fresh as that found in any daily paper to-day. Speaking of newspapers, films and radio as the means for "mass communication" Prof. Albion said that the chief implied danger of these is that their great influence may be abused by the small groups which control them.

\section{Work of the Government Chemist}

THE report of the Government Chemist on the work of the Government Laboratory for the year ending March 31, 1933, shows that the total number of samples examined, nearly 461,000, was smaller by about 12,000 than last year's figure. Work actively progressed in the elucidation of new and improved methods, and in the technique of examination of materials becoming subject to new duties. For example, orders are made from time to time under the Import Duties and Ottawa Agreements Acts which involve changes in the incidence of duty and require the carrying out of many difficult analyses, of a wide range of products ; moreover, such analyses frequently require investigation and general inquiries before decisions can be reached. Among the specific investigations mentioned is one group on Trinidad natural gas, which was found to contain only negligible traces of helium. In 20 instances out of 105 samples of non-alcoholic beer, herb beer, and beer substitutes examined, the alcohol ranged from 2 to 6 per cent of proof spirit. Samples of storm water taken from surface water drains in London districts were examined chemically and bacteriologically in connexion with an inquiry into the character of the water concerned; the examination of numerous samples of sea-water has also been continued as a share in an international scheme for the collection of data for hydrographic research. Another phase of the work is designed to ascertain the condition of fishing streams from the point of view of fish life, and the effect of certain types of pollution on fish food. Reference is again made to the fact that since there are no regulations relating to the marking of skimmed or partly skimmed milk cheese, and since there is no standard for cream in Great Britain, no exception could be taken to deficiencies in the fat content of these foods. 